\title{
Contents of Volume 112 (1997)
}

\section{Authors and Titles}

AVALlone, CHARLENE (Kailua, HI). What American Renaissance? The Gendered Genealogy of a Critical Discourse

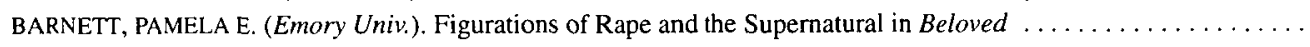
BARTHES, ROLAND. Reflections on a Manual (Criticism in Translation series). Translation and introduction by Sandy

Petrey (State Univ. of New York, Stony Brook) .

(Oct.) 1102

(May) 418

BUELL, LAWRENCE. See Teaching English in American Universities-1895.

CAUGHIE, PAMElA L. (Loyola Univ., Chicago). Let It Pass: Changing the Subject, Once Again . . . . . . . . ..... (Jan.)

(Jan.) 69

DIMOCK, WAI CHEE (Yale Univ.). A Theory of Resonance

(Oct.) 1060

ESKIN, MICHAEL. See YAKUBINSKY, LEV PETROVICH.

GILBERT, SANDRA M. (Univ. of California, Davis). Presidential Address 1996. Shadows of Futurity: The Literary

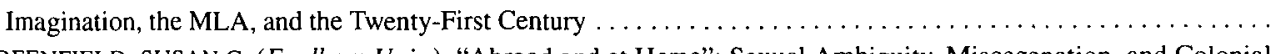

GREENFIELD, SUSAN C. (Fordham Univ.). "Abroad and at Home": Sexual Ambiguity, Miscegenation, and Colonial

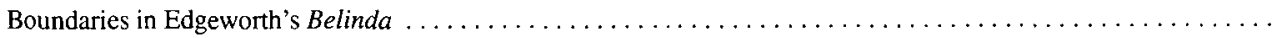

HENDERSON, ANDREA (Univ. of Michigan, Ann Arbor). Passion and Fashion in Joanna Baillie's "Introductory

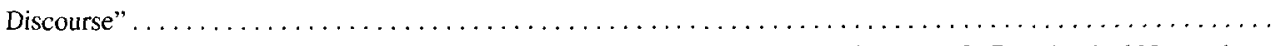

HERMAN, DAVID (North Carolina State Univ.). Scripts, Sequences, and Stories: Elements of a Postclassical Narratology HOVEY, JAIME (Rutgers Univ., New Brunswick). "Kissing a Negress in the Dark": Englishness as a Masquerade in

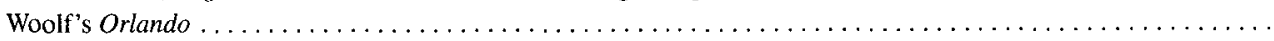

KELLER, BETSY (Rutgers Univ., New Brunswick). Rereading Flaubert: Toward a Dialogue between First- and Second-

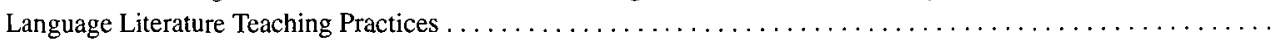

KRAMNICK, JONATHAN BRODY (Rutgers Univ., New Brunswick). The Making of the English Canon ...........

KRAMSCH, CLAIRE (Univ. of California, Berkeley). Guest Column. The Privilege of the Nonnative Speaker ........
LARSON, RUTH (Texas A\&M Univ, College Station). Ethnography, Thievery, and Cultural Identity: A Rereading of

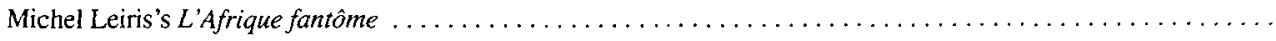

LYDENBERG, ROBIN (Boston Coll.). Freud's Uncanny Narratives $\ldots \ldots \ldots \ldots \ldots \ldots \ldots \ldots \ldots \ldots \ldots \ldots \ldots$

MARTIN, BIDDY (Cornell Univ). Introduction. Teaching Literature, Changing Cultures .........................
NOLAND, CARRIE (Univ. of California, Irvine). Poetry at Stake: Blaise Cendrars, Cultural Studies, and the Future of

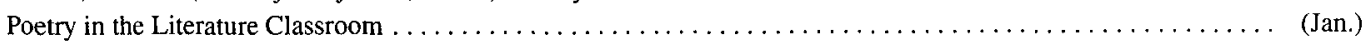

PETREY, SANDY. See BARTHES, ROLAND.

RAMAZANI, JAHAN (Univ. of Virginia). The Wound of History: Walcott's Omeros and the Postcolonial Poetics of

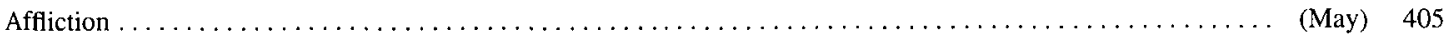

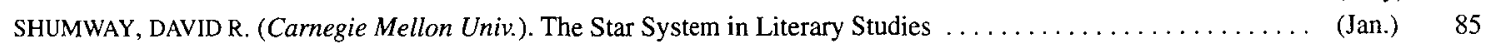

STATEN, HENRY (Univ. of Utah). The Decomposing Form of Joyce's Ulysses . . . . . . . . . . . . . . . . . . (May) 380

Teaching English in American Universities - 1895. Introduction by Lawrence Buell (Harvard Univ.) . . . . . . . . . (Jan.) 76

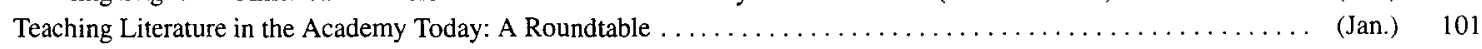

YAKUBINSKY, LEV PETROVICH. On Dialogic Speech (Criticism in Translation series). Translated, edited, and with an

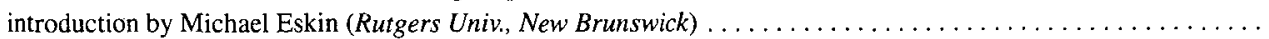




\section{Miscellaneous}

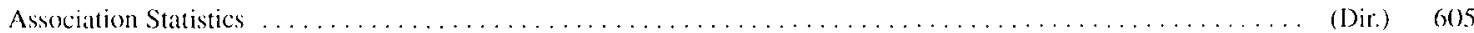

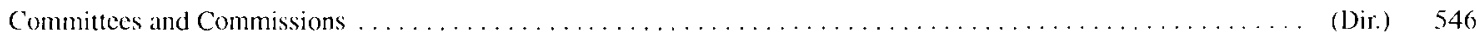

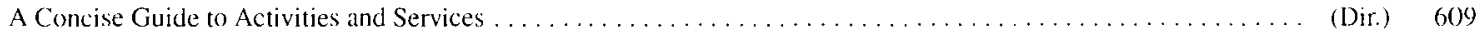

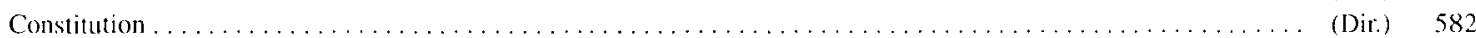

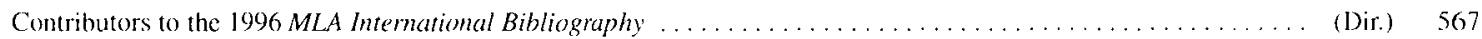

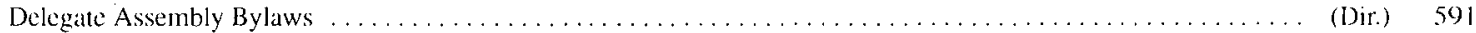

Departmental Administrators

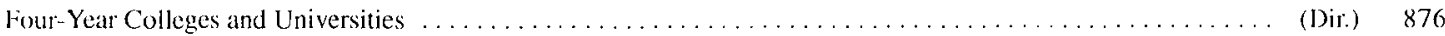

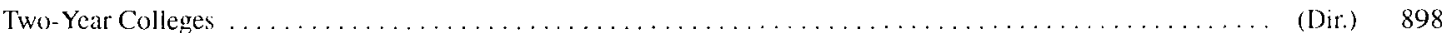

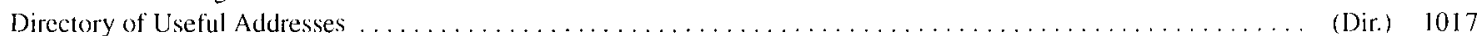

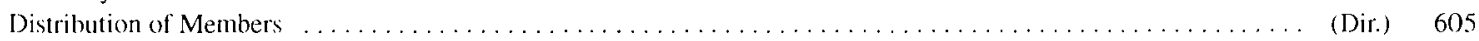

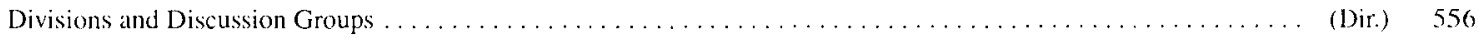

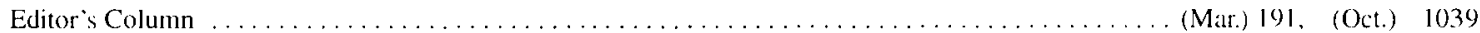

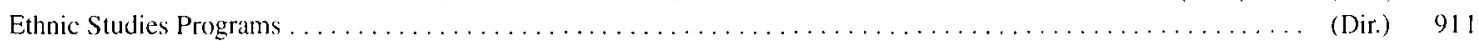

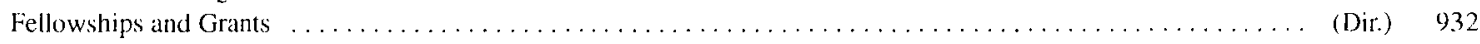

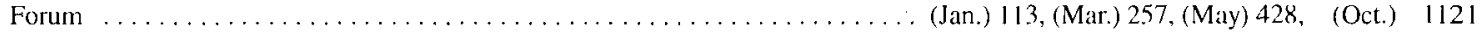

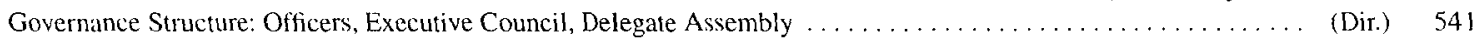

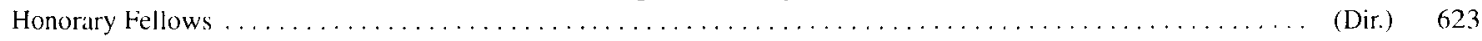

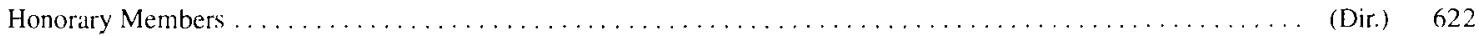

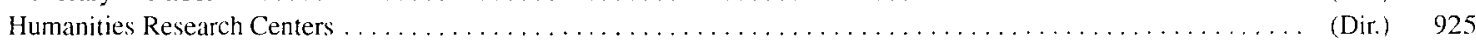

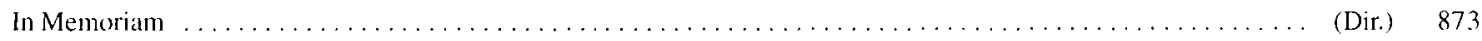

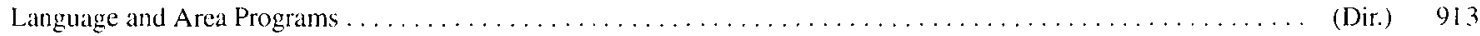

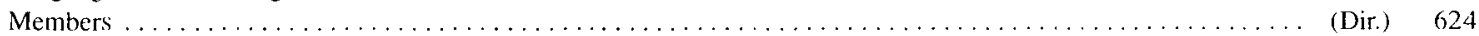

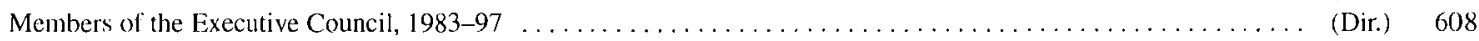

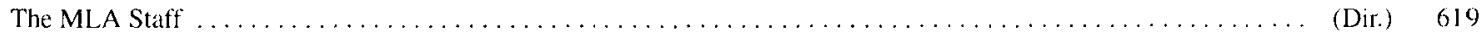

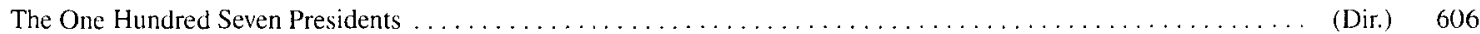

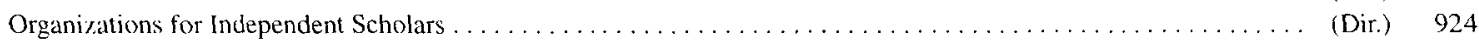

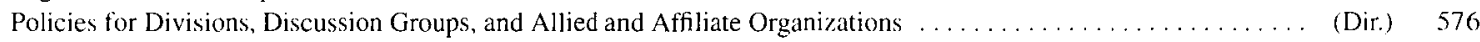

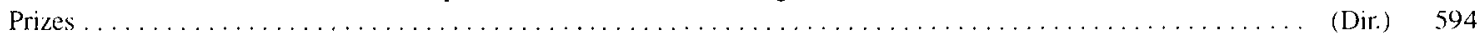

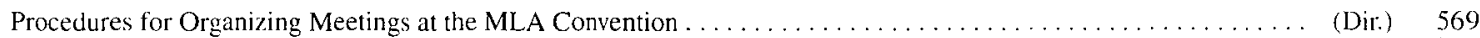

Professional Notes and Comment ...................... (Jan.) 152, (Mar.) 310, (May) 480, (Dir.) 949, (Oct.) 1164

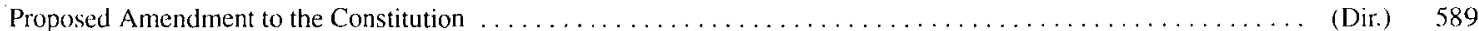

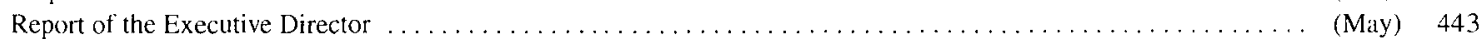

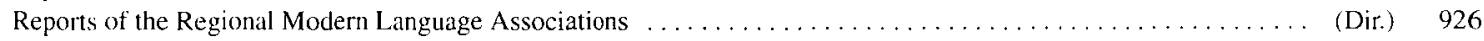

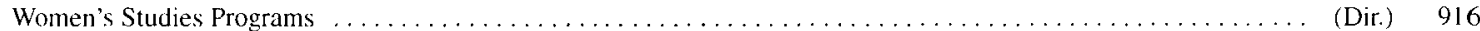




\section{RoadFrames}

The American Highway Narrative KRIS LACKEY

"Without a doubt Kris Lackey's

RoadFrames is the finest interpretive analysis of U.S. highway literature ever written. ... Lackey offers compelling insights about our national obsession for movement."-Douglas Brinkley, author of The Majic Bus: An American Odyssey $\$ 30$ cloth

The Willa Cather Scholarly Edition

\section{A Lost Lady WILLA CATHER}

Edited by Charles W. Mignon and Frederick M. Link, with Kari A. Ronning Historical essay by Susan J. Rosowski Explanatory notes by Kari A. Ronning One of Willa Cather's classic novels about life on the Great Plains. The Willa Cather Scholarly Edition of $A$ Lost Lady is edited according to standards set by the Committee for Scholarly Editions of the Modern Language Association.

$\$ 55$ cloth

Now in paper from

The Willa Cather Scholarly Editions

My Ántonia

Edited by Charles Mignon with

Kari Ronning

Historical essay and explanatory notes by James Woodress

Illustrations by W. T. Benda

\$14.95 paper

\section{O Pioneers!}

Edited by Susan J. Rosowski and Charles

Mignon with Kathleen Danker

Historical introduction and explanatory notes by David Stouck

\$12.95 paper
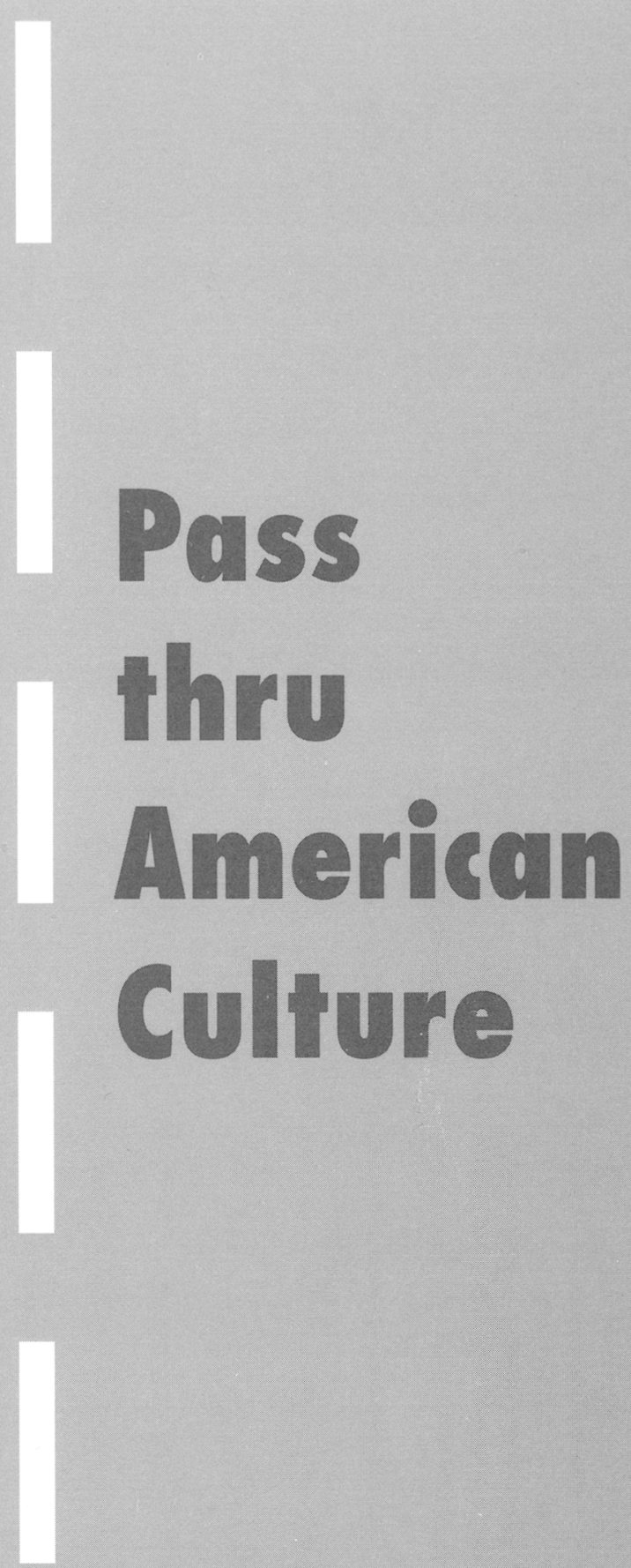
ANN CHARTERS - SAMUEL CHARTERS LITERATURE AND ITS WRTIERS

LITERATURE AND ITS WRITERS An Introduction to Fiction, Poetry, and Drama

\author{
Ann Charters, University of Connecticut
} Samuel Charters

1997/cloth/2151 pages/\$32.50 net Instructor's Manual

the first introduction to literature truly to give writers their say, this groundbreaking new anthology is built on the premise that those who write literature offer the most useful perspectives on it includes 160 commentaries, many by the same authors whose stories, poems, and plays appear in the book the most comprehensive selection of fiction in any introduction to literature, chosen by the editor of the best-selling introductory fiction text 77 alphabetically arranged stories and 55 commentaries a gathering of 317 poems and 61 commentaries uniquely emphasizes poets as well as poetic analysis - judicious selection of 19 plays and 44 commentaries chosen for student appeal and instructional flexibility 9 writers covered in depth through multiple works and Casebooks of commentaries - more than in any other text - innovative apparatus maintains the focus on the writers abundant but unobtrusive instruction in critical thinking, reading, and writing about literature new supplemental guide to writing research papers $\mathbf{a}$ comprehensive Instructor's Manual $\mathbf{C D}$-ROM on the poetry of Robert Frost available upon adoption

"The content is comprehensive and the examples are well-chosen. I particularly like the sense of history and the use of details that personalize literature and its writers... The text 'talks to' students as it provides the means for them to become better readers, writers, and thinkers."

$$
\text { - Iris Rose Hart, Santa Fe Community College }
$$

"I am greatly impressed by the wide variety of the selections and the pluralistic approach to cultures and forms. ... I am also drawn to the inclusion of 'commentaries' and 'casebooks' that demonstrate how the literature is situated within different rhetorical communities."

$$
\text { — Linda Bensel-Meyers, University of Tennessee - Knoxville }
$$

\title{
BEDFORD BOOKS
}

For examination copies, visit www.bedfordbooks.com or call 1-800-446-8923. 